\title{
VIII
}

\section{PROSTITUTION IN RELATION TO VENEREAL DISEASES}

By W. METCALFE CHAMBERS, M.D., Singapore.

Prostitution has been defined by Flexner as " more or less promiscuity of sex relationship for pay, or its equivalent," and, more briefly, by the "Encyclopædia Britannica " as " promiscuous unchastity for gain."

From the standpoint of venereal diseases, prostitutes may be classified as-
(i.) Professional prostitutes.
(ii.) Amateur prostitutes.

(i.) Professional prostitutes may be subdivided into known prostitutes, and clandestine or " sly" prostitutes. The known women are those who devote all their time to their profession. In France, Belgium and Italy many of them live and carry on their profession in brothels which are licensed by the police. In Germany thay are simply registered, and have to submit to certain regulations and restrictions. The vast majority of " whole-time" prostitutes are to be found only in the large towns, and they frequently move from one city to another. Clandestine, or sly, prostitutes are those who ply their trade more or less intermittently, or follow some legitimate occupation in addition. They do not live in brothels or register with the police. They permeate all strata of society and greatly outnumber the "known" women. In countries where registration exists the clandestine are computed to outnumber the inscribed women by, in some cities, as many as 20 to I.

(ii.) Amateurs are, for the most part, girls and women who bestow their favours upon selected partners for a variety of considerations other than a cash payment. It was found that, during the war, about 50 per cent. of infected members of the fighting forces contracted their diseases from " amateurs."

In cities where registration exists it is possible to form an approximate estimate of the ratio of prostitutes to 


\section{PROSTITUTION AND VENEREAL DISEASE}

the total population by taking the number of inscribed women and adding ten clandestine, including amateur, for each inscribed prostitute. Flexner estimates that there are from five to twenty of the former for each one of the latter.

\begin{tabular}{|c|c|c|c|c|c|}
\hline & & Population. & $\begin{array}{l}\text { Number of } \\
\text { inscribed } \\
\text { prostitutes. }\end{array}$ & Number of others. & $\begin{array}{l}\text { Ratio of all } \\
\text { prostitutes to } \\
\text { population. }\end{array}$ \\
\hline Paris & & 2,888 , I IO & 6,000 & 60,000 & I to 43 \\
\hline Berlin . & . & $2,07 \mathrm{I}, 257$ & 3,559 & 35,590 & I ,, 52 \\
\hline Vienna & . & $2,031,498$ & I, 689 & I 6,890 & I , IO9 \\
\hline Rome . & & $542, \mathrm{I} 23$ & 225 & 2,250 & I , 219 \\
\hline Budapest & • & $880,37 \mathrm{I}$ & 2,000 & 20,000 & I , 40 \\
\hline Stockholm & • & 346,599 & 554 & 5,540 & I ,, 57 \\
\hline Brussels & $\cdot$ & 659,000 & 182 & $I, 820$ & I , , 329 \\
\hline Geneva & ${ }^{\circ}$ & I 54, I 59 & 86 & 860 & $I,, I 63$ \\
\hline
\end{tabular}

The foregoing figures have been compiled from statistics published by Flexner in "Prostitution in Europe," in I9I4. The marked variation between the various cities is most probably due to the difference with which the regulations are enforced by the different authorities, some being much more rigidly enforced than others. This is, probably, the reason why Paris shows a ratio of I to 43 (obviously too high) compared with a ratio of I to 329 for Brussels, which can hardly claim to have a moral standard so high, compared with Paris, as the figures would indicate. The mean average of all the cities enumerated gives a ratio of $\mathrm{I}$ in I26, which is probably approximately correct for the ratio of prostitutes of all classes-inscribed, clandestine and amateur - to the population of those cities. As most of the prostitutes are concentrated in the large towns it is obvious that the ratio for the whole population must be very much lower.

The amount of venereal disease in any community must depend not only on the number of prostitutes, but to a great extent upon the percentage of such women who are suffering from disease in an infective stage. There is evidence to show that prostitutes become infected early in their career. Flexner states that out of 3,34I cases of obviously infectious syphilis in Viennese prostitutes, 44.9 per cent. were between fifteen and twenty years of age, 38.I per cent. between twenty-one and twenty-five. 


\section{BRITISH JOURNAL OF VENEREAL DISEASES}

At the State Reformatory for women at Bedford Hills, New York, 466 prostitutes were subjected to serum tests with the following results :-

Gonorrhœa (complement fixation test, ice-box method)

Positive . . . . 65.6 per cent.

Negative . . . . $2 \mathrm{I} \cdot 7$,

Doubtful . . . . I2.6 ,

Syphilis (Wassermann reaction, ice-box method)-

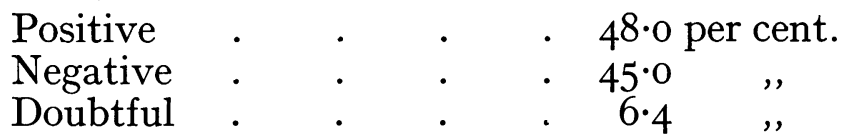

Of the 466 girls tested only 50 (I0.7 per cent.) were found to be free from venereal disease ; I70 (36.4 per cent.) gave positive reactions for both syphilis and gonorrhœa ; $27(5.79$ per cent.) were positive for syphilis only ; and II7 (25. I per cent.) were positive for gonorrhœa only.

There is little doubt that simple clinical examination, as carried out in the cities where regular medical examination exists, misses a very large percentage of disease.

Guth tells of a series of cases, 35 per cent. of which showed clinical symptoms of gonorrhœa ; the microscope showed 90 per cent.

The figures for three years (one with clinical examination only, and two with clinical and microscopical examination) at Budapest are instructive :-

\begin{tabular}{c|c|c|c}
\hline Year. & $\begin{array}{c}\text { No. of enrolled } \\
\text { prostitutes. }\end{array}$ & $\begin{array}{c}\text { Total cases of venereal } \\
\text { disease diagnosed. }\end{array}$ & \\
\cline { 2 - 3 } I907 & I,7I7 & 884 & No microscope used. \\
I908 & I,9I4 & 2,775 & Microscope used. \\
I9II & 2, I97 & 2, IOO &,$"$ \\
\hline
\end{tabular}

It is evident, therefore, that if regular examination is to be effective it must be of the completest possible kind, and must comprise clinical and microscopical tests at every examination, and serum tests at frequent intervals.

Thiebierge, of St. Louis Hospital, Paris, considers that there is much less probability of contracting venereal disease from a licensed prostitute who is properly examined at least twice a week than from an unlicensed amateur. It is more than doubtful, however, whether the proper 


\section{PROSTITUTION AND VENEREAL DISEASE}

examination of the large army of professional women is feasible if it is to include clinical, microscopical, and serum tests.

Iwan Block states that the problem of prostitution must be approached from many sides, because the causes that have to be considered are manifold, alike anthropological, social, and psychological, in their nature. From the earliest historical times attempts have been made to solve the problem. From the time when Christianity gained full political power, prostitution has again and again been prohibited under the severest penalties, but always in vain. An example of the magnitude of the task of repression is furnished by modern conditions in Chicago. The Vice-Commissioners of that city estimate that prostitutes in the disorderly houses known to the police-leaving out of account all prostitutes in flats, rooms, hotels and houses of assignation, and also taking no account of clandestine prostitutes-receive I5,I80 visits from men daily, or 5,540,700 per annum.

Most European countries have at some time tried to control prostitution by a system of regulation comprising the licensing of brothels, the registration of women, the periodical examination of registered prostitutes, and penalties for infringement of the regulations. There is, now, a strong consensus of opinion that such regulation has failed to reduce the incidence of venereal disease. There have been four main causes of the failure: (I) It has been found impossible to enrol more than 5 to 20 per cent. of all prostitutes; (2) the medical examinations have proved unreliable, uncertain, and misleading in their attempts to find which women were diseased and which healthy ; (3) it has proved extremely difficult to decide when a woman once diseased ceases to be capable of conveying infection; (4) the police entrusted with the execution of the regulations have been subjected to temptations which they have been unable to resist. Therefore there has been extensive evasion and connivance.

In Great Britain the Contagious Diseases Act, which was in force from I864 till I886 in certain military areas, aimed at :-

(I) The compulsory periodical medical examination of prostitutes. 


\section{BRITISH JOURNAL OF VENEREAL DISEASES}

(2) Their detention in hospitals when found diseased.

(3) The granting of certificates of freedom from disease to non-infected women.

(4) The arrest and compulsory examination of prostitutes who could not produce such a certificate.

The Act was repealed in I886, and statistics did not show that the Act had been efficacious in reducing the incidence of venereal disease in the Army.

Flexner states that to the licensing or toleration of outright houses of prostitution public opinion in Europe has become increasingly hostile. With regard to the regulation of prostitutes, Flexner further says that, in most cities it is moribund, and in many quite dead. As compared with the total volume of prostitution the enrolment is at best unimportant, and at the worst altogether negligible.

The United States, Canada, Australia, Norway, Sweden, Denmark and Czecho-Slovakia have all abolished regulation of prostitution, but all these countries have instituted instead a system of anonymous notification, compulsory treatment, power to detain in a hospital infected persons till cured, and penalties for non-compliance with the legal measures.

The only countries which, at present, rely entirely upon a voluntary non-compulsory system for combating venereal disease are Great Britain and Holland. These countries rely upon the free, confidential, expert treatment of all sections of the community, without compulsion. That their policy is meeting with success is shown by the following figures for England and Wales :-

\begin{tabular}{c|c|c|c|c}
\hline Year. & Syphilis. & Gonorrhœea. & $\begin{array}{c}\text { Total } \\
\text { venereal disease. }\end{array}$ & $\begin{array}{c}\text { Total No. of } \\
\text { attendances. }\end{array}$ \\
\cline { 2 - 2 } I920 & 42,805 & 40,284 & $85,53 \mathrm{I}$ & $\mathrm{I}, 488,5 \mathrm{I} 4$ \\
$\mathrm{I921}$ & 32,733 & 32,433 & 66,820 & $\mathrm{I}, 6 \mathrm{I} 2,952$ \\
I922 & 25,762 & 29,477 & 56,347 & $\mathrm{I}, 560,568$ \\
I923 & 23,927 & 30,908 & 55,945 & I,605,6I7 \\
\hline
\end{tabular}

In Sweden and in some other countries the system provides that any infected person may report the name and address of the infecting person. Such can be called upon to produce a medical certificate, and if certified 


\section{PROSTITUTION AND VENEREAL DISEASE}

to be suffering from venereal disease can be compelled to undergo treatment till free from infection. If the infected person fails to undergo voluntary treatment he or she can be detained in a hospital for that purpose.

The following figures give the number of persons reported as sources of contagion in Sweden in the year r924:-

\begin{tabular}{|c|c|c|c|}
\hline & Towns. & Country. & Total. \\
\hline $\begin{aligned} \text { Number reported } & . \\
,, & \text { treated } \\
, & \text { found free from disease } \\
, & \text { not traced }\end{aligned}$ & $\begin{array}{l}659 \\
396 \\
154 \\
109\end{array}$ & $\begin{array}{r}383 \\
2 \mathrm{I} 4 \\
108 \\
6 \mathrm{I}\end{array}$ & $\begin{array}{r}\mathrm{I}, 042 \\
6 \mathrm{IO} \\
262 \\
\mathrm{I} 7 \mathrm{O}\end{array}$ \\
\hline
\end{tabular}

In those countries which have abandoned all attempts to regulate and control prostitutes, the authorities are concentrating on attempts to seek out, and treat, as many venereally diseased members of the community as possible, either by attracting voluntary patients to the free clinics, as in England, or by measures of compulsion, as in Scandinavia. All these countries, with their varying methods, show a steadily decreasing incidence of venereal disease. It is probable that other factors are at work, besides the various systems in these countries, which are contributing to this desirable end. If for any reason in the future there should be an increase of venereal disease throughout Europe the systems now in force will be called upon to prove their value in controlling venereal disease.

Before leaving the subject of regulation it is significant to note that France, which has adhered to regulation longer than most countries, has recently decided not to license any more brothels, and to allow all present licences to lapse in due course. It is estimated that within nine years there will not be any licensed brothels in France.

At a meeting held in Paris on October 9th, I925, the Council of the Union Internationale contre le Péril Vénérien made the following recommendations regarding prostitution :-

(I) The suppression of the regulation of prostitution.

(2) That Governments should take measures against 


\section{BRITISH JOURNAL OF VENEREAL DISEASES}

the social causes which provoke and maintain prostitution.

(3) The adoption of measures to bring about the suppression of :-

(a) Solicitation.

(b) Instigation to immorality, particularly to the corruption of the young of either sex, by all means, even those indirectly obscene (films, advertisements, etc.).

(c) Any act of enticing, leading astray or inducing to immorality any person irrespective of age or sex.

(d) All individuals who cause it to be known, while concealing the nature of their offer in equivocal language, that they practise prostitution or facilitate its practice by others.

Another organisation which strives for the abolition of regulation is the International Abolitionist Federation, which declared its aims in resolutions adopted at a meeting held at Graz in September, I924. Its aims are : (I) The impartial application of the necessary measures to every individual without distinction; (2) the education and protection of young people of both sexes and the family, combined with an entirely voluntary system for the treatment of venereal diseases ; (3) the exclusion of all compulsory measures, such as compulsory notification and treatment, or the coercive medical examination of persons suspected to be venereally infected.

It is evident that regulation must retire, defeated by the volume of public opinion represented, on the Continent by the societies just mentioned, and in England by the British Social Hygiene Council. That regulation has failed in Europe cannot be doubted, and the causes of failure have already been stated, but to an unbiased observer it seems that, if it were ever possible in any community to apply the system of regulation in a thoroughly efficient manner, its principles contain the elements for success in coping with venereal disease through the public control of prostitution. Whether the efforts of the anti-regulationists will be eventually more successful than the regulationists remains to be proved. 


\section{PROSTITUTION AND VENEREAL DISEASE}

The history of the campaign against prostitution since the earliest times shows that systems of toleration, regulation, abolition, and prohibition have more or less alternated, and that all have failed to reduce prostitution to a manageable limit. No doubt history will continue to repeat itself in this, as in so many other departments of history, in the years that stretch ahead.

\section{REFERENCES}

Abraham Flexner. " Prostitution in Europe."

GEORGE K. KNEELAND. "Commercialised Prostitution in New York City."

IwAN Block. "The Sexual Life of Our Times."

Havelock Ellis. "The Task of Social Hygiene."

J. Schrank. Die Prostitution in Wien.

WANSEY BAYLy. "Venereal Disease; its Prevention, Symptoms and Treatment."

" Encyclopædia Britannica," IIth Edition.

The Shield, January-February, 1925. 